\title{
Notes on the Marine Invertebrate Fauna of Plymouth for 1892.
}

\author{
By \\ Walter Garstang, M.A., \\ Naturalist in Charge of the Dredging Operations, M.B.A.
}

THe following faunistic notes are offered as an indication of the chief results which have characterised our collecting operations during the present year. It is hoped that, short as they are, they may prove serviceable to British naturalists desiring to pursue special researches in marine zoology, but undecided as to the locality most likely to meet their needs. The notes are incomplete, owing to my absence from Plymouth during the earlier part of the year; but they are sufficient for the formation of an inference, since the results here described were obtained for the most part during only a fragment of the year-from June to September.

I have not discussed the peculiarities which have characterised the floating fauna, since Mr. Bles, who has been specially pursuing planktological researches, is publishing a note upon his observations in the same number of this Journal.

In future numbers I hope to give a systematic account of the fauna characterising the different bays and natural areas which are within the reach of the routine dredging and collecting operations of the Laboratory. Such an account will, I trust, be useful to naturalists visiting the Laboratory, and will also be so arranged as to form a contribution towards the general subject of marine bionomics.

The dredging, tow-netting, and trawling work of the Laboratory is, however, carried on at present under difficulties* which can hardly be adequately realised. The frequent breakdowns of the small and antiquated launch belonging to the Association seriously interfere with the continuity of our work, and needlessly limit the scope of our operations. A new and seaworthy steamboat has become an absolute necessity.

Porifera.-A specimen of Leucosolenia lacunosa (Bwk.), a rare and

* These difficulties, I learn, are, happily, nearly at an end (October 17th). 
beautiful calcareous sponge, was dredged* in $25 \mathrm{fms}$. on September 14th, attached by its slender stalk to an old egg-case of Scyllium canicula, which was itself adhering to the stem of a Gorgonia.

HydrozoA.-A colony of Norman's Tubiclava (Merona) cornucopiæ, consisting of from 90 to 100 polyps, was dredged in 15 fms. water on June 10th. The colony covers almost the whole of the upper side of the shell of an Aporrhais, tenanted by a Phascolion strombi. Several interesting points, in which I have been able to supplement Dr. Norman's original description, will be found described in a paper contributed by me to the Transactions of the Devonshire Association for the present year. The original specimens of $T$. cornucopix were dredged thirty years ago among the Shetlands, in from 80 to 100 fathoms of water.

Several additional colonies of Haloikema Lankesterii (G. C. Bourne) have been dredged, but the description of these is for the present deferred.

Scyphozon.-In a little creek beyond the breakwater Haliclystus octoradiatus ( = Lucernaria auricula) has been discovered in hundreds, attached to Ceramium and Enteromorpha, between tidemarks. The early part of the spring would be the time at which the development of this form could be followed out.

Anтноzод.-The Actinians of Plymouth present a valuable field for special investigation. On June 28 th a specimen of one of the varieties of Eloactis Mazeli (Jourd.) was trawled by us a few miles off the Mewstone, and furnishes an interesting addition to the British fauna. It has been fully described in my paper read to the Devonshire Association last July.

Actinia equina, Anemonia sulcata, Cereus pedunculatus (S. bellis), Thoë sphyrodeta, Cylista undata (S. troglodytes), Urticina felina (T. crassicornis), and Corynactis viridis are all common at Plymouth. Cylista viduata is rare within the Sound, although common enough in the neighbourhood. Bunodes coronata and Ballii both occur, the former in Whitsand Bay, the latter on the breakwater. Of Bunodes Ballii, the typical pink-spotted variety, which is very common on the shores of the Isle of Wight, is rare here, and is replaced by the varieties dealbata and livida of Gosse. In addition to the above, several interesting forms that appear to be undescribed are quite common in certain localities.

Turbellaria. - Mr. Gamble's researches during the present summer have revealed the existence of a Rhabdocæle fauna unparalleled in the number of its species, and upon which we may expect a special report in an early number of the Journal.

Nemertea.-For a similar reason there is no need that anything

* Two additional specimens have since been taken. 
should here be stated concerning the Nemertines of Plymouth, since they are being specially investigated by Mr. Riches.

AnNelida.-This large group will require considerable time before it can be adequately treated from a faunistic point of view. The dredge is constantly bringing to light the existence of species whose presence has been hitherto unsuspected. The permanent haunts of Gattiola spectabilis have been discovered. Myxicola has been added to our lists. Staurocephalus rubrovittatus (Grube), a remarkable little Eunicid which has hitherto been found* exclusively, I believe, in the Mediterranean, has been taken on several occasions. Where the bottom is muddy, a species of Chrtozone has been taken in quantity, and Polydora ciliata builds its mud tubes in thousands upon the stones and shells brought up in the dredge.

The Gephyrea are represented by a small species of Phascolosoma, which is abundant in the crevices of shaly rocks between tide-marks, Phascolion strombi, and Thalassema Neptuni.

Phoronis, whose occurrence at Plymouth I recorded some time since, proves to be quite plentiful in certain parts of the Sound, and its beautiful larva has been a feature of the autumn tow-nettings.

PolyzoA.-The localities for the different members of this large group are being gradually established. Beyond the fact of the common occurrence of Pedicellina, however, there is nothing that calls for special notice, unless it is that Crisia denticulata, which Mr. Harmer, in his paper on the British species of Crisia, mentions as having been seldom found at Plymouth, proves to be abundant in the deeper waters a few miles outside the breakwater.

Echinodermata.-Antedon rosacea remains a constant element in the fauna, and its Pentacrinoid larva has been taken in some numbers during the autumn.

Solaster papposus has been the most plentiful starfish this year ; and, among Ophiuroids, Amphiura elegans, Ophiothrix pentaphyllum, and Ophiocoma nigra.

Holothuria nigra and Ocnus brunneus have been taken in quantity.

Mollusca.-Numbers of minute specimens of Solen were fished during June, and showed the early development of the gill-plates in a beautiful manner through their perfectly transparent shells.

The principal additions to the Gastropod fauna have been in the Opisthobranchiate section, but it may be mentioned that two favourite Prosobranchs, Emarginula reticulata and Phasianella pullus, have been found in quantity, the former inhabiting shell-banks in about seven fathoms of water, the latter feeding upon filamentous red-brown algæ in various parts of the Sound.

* Grube, I find, records a specimen in his St. Mâlo list, so that the species is probably not uncommon in the Channel waters.

NEW SERIES.-VOL. II, NO. IV. 
Philine punctata, of which only a single specimen was recorded in my list of 1890 , I find to be plentiful in twenty fathoms among shells and stones covered with Bugula.

Oylichna truncata has been met with several times, but its real locality is yet to be discovered.

Young specimens of Oscanius membranaceus were dredged repeatedly in the Sound during September, and on the night of the 21 st were found actively swimming in some numbers at the surface of the sea.

Six additional specimens of Lomanotus were dredged within the Sound during June and September, but as yet no large individuals have been met with.

Cratena amcena and olivacea have been obtained rather often, and the same remark applies to Jorunna Johnstoni and Lamellidoris aspera. Calma glaucoides was dredged on June 18th, and a beautiful specimen of Idalina elegans, grotesquely embedded within a small Cynthia upon which it had been feeding, on July 30th. Mr. Gamble twice brought me specimens of a little Alolid, which proved upon examination to be the Embletonia pulchra of Alder and Hancock, although much paler in coloration than the type of that species. Amphorina cœrulea, a species which has not been met with on the English coasts since the time of Montagu, was dredged on September 12th. The individual captured was $3 \mathrm{~mm}$. in length, and the whole of the body with the head and tentacles was of a semi-transparent pale greenish colour. The gorgeous cerata are the chief peculiarities of this little creature. The colour of these is partly due to the cæca shining through, and to the superficial markings of the skin. The cæca in this case were deep sage-green, granulated, nearly filling the cerata. The upper half of each ceras was marked by conspicuous bands of colour-a rather broad band of glistening dots of cerulean blue, bounded above and below by a ring of bright yellow pigment-cells, branched and reticulating. There was no trace of orange. The rhinophores were rather short and conical, not filiform, as Vayssière found to be the case at Marseilles ('Ann. Mus. Hist. Nat. Marseille,' t. iii, mem. 4, pl. i, fig. 5), nor nearly so long as represented in his figure, perhaps because they were incompletely extended. They were held vertically upwards, parallel with each other; while the oral tentacles, slightly dilated towards their extremities, were held horizontally, and curved outwards on each side. There were seven rows of stout clavate cerata $(2 \times 2,3,4,3,2,2,1)$. The first three rows were close together, forming a cluster as in Cratena; this was separated from the fourth row, and the posterior rows from one another, by a considerable interval.

In August two specimens of Antiopa hyalina were dredged, one 
of them $5.5 \mathrm{~mm}$., the other $9.5 \mathrm{~mm}$. in length. This rare species furnishes another valuable addition to our fauna.

Perhaps the most interesting addition of all, however, has been the rediscovery of D'Orbigny's Stiliger bellula, the Calliopæa bellula of that author's beautiful memoir on new species and genera of Nudibranchs observed on the coast of France. Ten individuals were dredged in Cawsand Bay on the 3rd of August, but I have hardly a remark to add to the admirable description of the external form, colour, and habits of the species which the talented French naturalist gave sixty years ago. The bearings of the anatomy of this primitive form upon the epipodial theory of the cerata must be important, since it occupies a position intermediate between Hermæa and the Aolids, which have been shown by Prof. Herdman to possess a ceratal innervation constructed upon two distinct types.

Among Cephalopoda, Eledone cirrhosa and Sepiola atlantica are plentiful ; Rossia macrosoma has been taken twice this autumn. The smallness and unseaworthiness of our present steamboat unfortunately prevent us from visiting the proper localities for the larger species of cuttle-fish, and we are therefore unable to obtain good specimens of forms like Loligo Forbesii except on rare occasions.

Crustacea.-An Amphipod, which Dr. Norman has kindly identified for me as Unciola crenatipalma, Bate (sp.), is plentiful among shells and stones on a muddy bottom at a depth of twenty fathoms. The two sexes were described by Spence Bate under the names Dryope crenatipalma $(f)$ and $D$. irrorata $(\delta)$, and wrongly removed by him from the genus Unciola, to which Gosse had rightly referred the latter " species," owing to his inability to discover the secondary appendage of the first antennæ. A minute one-jointed appendage, however, is constantly present, as Stebbing has already stated. The species is readily recognised, when alive, by its form and colour, the latter being yellowish, much speckled with white. It appears to be very locally distributed, for it is not included in Mr. David Robertson's recent catalogue, in Mr. A. O. Walker's lists of the L. M. B. C. Amphipoda, or in Carus's Prodromus Faunæ Mediterraneæ.

Corophium grossipes (longicorne) and $O$. crassicorne (Bonellii) inhabit their special localities in thousands.

Among Isopoda, Apseudes talpa has been taken in some numbers, while species of Anceus, Munna, and Jæra are abundant. On June 19th I found a male Anthura gracilis, $4 \mathrm{~mm}$. long, provided with an antennal flagellum of nine joints, each of which was encircled by a dense ring of long slender hairs. Another specimen, dredged on September 16th, was $5 \mathrm{~mm}$. long; the antennæ were as long as the head and first two segments of the pereion, and each of the twelve joints of the flagella was encircled with hairs, as in the preceding 
specimen. The discovery of these specimens confirms in an interesting manner the prediction of Norman and Stebbing concerning the secondary sexual characters of the adult male of this species (Trans. Zool. Soc., xii, p. 123).

A specimen of Idotea parallela (B. and W.) was dredged on June 8th in Cawsand Bay. It presented a curious appearance when alive, for it was inhabiting a piece of the stem of a dead Zostera plant, which it carried about with it like a caddis-worm in its tube. The thick, soft, white antennæ of this species are very characteristic, and were at first much more suggestive to me of the tentacles of a Polychæte than of Crustacean appendages.

Two species of Arcturus have been frequently taken among the filamentous Algæ to which they cling. Their peculiar form, colour, and habits of fixation render them excellent examples of protective adaptation.

The Cumacea are still under examination. Pseudocuma cercaria is abundant; and Iphinoë trispinosa, a species of Diastylis, and other forms, are plentiful in their respective localities.

Of the Schizopoda, Macromysis flexuosa (chamæleon of authors) has been very abundant this summer. Each time that I visited the estuary of the Yealm during July and August I found it at low tide swimming in countless myriads close to the water's edge. It is interesting to watch the behaviour of this Mysis when placed in a tank containing some of its piscine enemies. It is a good match for the sharpsighted but too eager wrasses, and, when pursued, generally manages to escape from them by darting swiftly away in an irregular zigzag manner; but the John Dory catches the Mysis easily by moving stealthily towards them by means of its almost invisible fins, and, when within reach, suddenly projecting its huge protrusible jaws, and sucking in the unsuspicious shrimps. The middle of July marked the height of the breeding season of this species.

The same may be said of Schistomysis spiritus, which was taken in considerable numbers in Whitsand Bay on July 15th, at which date all the individuals were of large size, and the marsupial pouches of the females were full of embryos. By August 3rd almost all the large individuals had disappeared, and the bottom net brought up thousands of small Schizopods, consisting chiefly of the young of this species. Along with them, however, were adult specimens of Gastrosaccus sanctus, and of a small robust species of Schistomysis, allied to $S$. arenosa, which seems to be new to science.

On the night of September 21st the Mysidæ Gastrosaccus Normani and Siriella jaltensis ( $S$. crassipes, G. O. Sars) were taken in the surface-net in about equal numbers (principally males). The former species was taken by the "Porcupine" in 1869, and by 
Norman off the south-west coast of Ireland in the following year, since which date it appears not to have been observed upon our coasts.

Our museum already contains a considerable collection of Decapoda, named by Prof. Weldon and Dr. Norman, which is all but representative of the fauna. The year's additions to this type collection consist of the species Xantho floridus, rivulosus, and tuberculatus, Hyas araneus, Achæus Cranchii (a valuable addition made by my assistant, Mr. Walker, in the spring), and Eupagurus Forbesii, which was added by Mr. Riches. The reserve stores of other interesting forms, e.g. Portunus arcuatus, Polybius Henslowii, Ebalia, Diogenes varians, Crangon Allmanni, have been considerably increased. 